\title{
Some considerations on the Center of the Main Interests as jurisdictional test under the European Insolvency Regulation
}

\author{
Patrick Wautelet \\ Professor of Law - University of Liège \\ Of Counsel - Stibbe (Brussels)
}

The EC Regulation on Insolvency Proceedings (the "Regulation"), which came into force on 31 May 2002, creates a common regime for the opening and the recognition and effects of insolvency proceedings throughout the European Union. It introduces the possibility to have pan-European insolvency proceedings, encompassing all assets and all liabilities of the debtor wherever located on the territory of the European Union. ${ }^{1}$ The significant advantages of this regime have been somewhat overshadowed by the controversy surrounding the concept of the debtor's "center of main interests" (known as the 'COMI').

As is well known, the center of the debtor's main interests plays a key role in the application of the Regulation. On the one hand, it constitutes the main jurisdictional test - the Regulation also uses another test for so-called secondary proceedings, which may be opened in the Member State where the debtor has an establishment. ${ }^{2}$ On the other hand, the location of the COMI is also decisive for the consequences of the insolvency. It determines the applicable law and thus the treatment afforded to creditors and, subject to some exceptions, to secured creditors. ${ }^{3}$ Whether one contemplates requesting the opening of insolvency proceedings or is drafting legal documentation for a financial transaction involving a foreign debtor, one must take great care to identify the debtor's COMI.

It is therefore surprising that little guidance is given in the Regulation as to how this jurisdiction test should be applied. ${ }^{4}$ Drawing on the Virgos-Schmit Report, the often quoted recital 13 of the Regulation's Preamble states that the "center of main interests" shall correspond to the place where the debtor conducts the administration of his interests on a regular basis and is therefore ascertainable by third parties. ${ }^{5}$ In the case of

Unfortunately, the Regulation is not applicable in Denmark.

The concept of 'establishment' does not seem to have given rise to controversy. It seems that the definition provided by Article $2(\mathrm{~g})$ of the Regulation provides sufficient clarity. For one application, see Telia Sonera AB v. Hillcourt (Docklands) Ltd, [2002] E.W.H.C. 2377 (Ch.), [2003] B.C.C. 856 Park J. (The debtor, Telia, was a Swedish company whose registered office was also in Sweden. A creditor was petitioning the court to open winding up proceedings. Having concluded that the debtor's COMI was located in Sweden, the Court looked at the secondary argument put forward by the petitioning creditor, which argued that the UK subsidiary of Telia could rank as an establishment of the parent. Justice Park did not elaborate on the issue, simply noting that "I do not think that there is any force in the submission that business premises of Telia's United Kingdom subsidiary company can rank as an "establishment" of Telia for the purposes of Article 3.2 of the Regulation »).

3 One notes with interest that the concept of center of the main interests has also been included in Section 1502(4) of the US Bankruptcy Code.

4 According to Prof. Fletcher, the absence of clear definition of the COMI is « singularly unhelpful»: I. FletCHER, Insolvency in Private International Law - National and International Approaches, $2^{\text {nd }}$ ed., OUP, 2005,366 at $\S 7.41$.

5 For a commentary on the various parts of this definition, see G. Moss in G. Moss et al (eds.), The EC Regulation on Insolvency Proceedings. A Commentary and Annotated Guide, OUP, 2002, at pp. 168174. 
companies, the place of the registered office is presumed to be the center of its main interests in the absence of proof to the contrary.

The absence of a clear definition is even more striking given that the concept of the COMI is a new one. ${ }^{6}$ According to Balz, who was instrumental in the drafting of the Regulation, this concept is an «entirely artificial term without precedent in any one State's national laws ».?

Against this background, it is easy to understand why the COMI has been the center of attention in the application of the Regulation by courts over the last years. Courts in various Member States have been struggling with the concept, attempting, not always in a convincing manner, to put some flesh on the bone provided by the Regulation. The case law has grown enormously.

The very first case, Enron Directo, already took most commentators by surprise. In this case which followed the disintegration of the Enron bubble, the English High Court agreed to open administration proceedings in relation to a company incorporated under Spanish law, an outcome which before the entry into force of the Regulation would have been very unlikely. ${ }^{8}$ The key in this somewhat mysterious case - no judgment was ever issued - was the fact that the 'headquarters functions' were carried out in London. According to the arguments put forward by the petitioner, "all of the principal executive, strategic and administrative decisions in relation to the financial and economic activity of the Company were conducted in London". The petitioner also mentioned that "the directors and head office decision makers were also based in London". In addition, the court was influenced by a number of additional elements which showed that high-level control was exercised from the Enron House in London. ${ }^{9}$

In a further development, the Chancery Division of the High Court was asked to make an administration order in respect of a company incorporated in the State of Delaware, U.S.A., where it also had its registered address. Based on the evidence given by the petitioner, the court found that the debtor's COMI was located in England, where it had a long-standing registration as an overseas company under the UK Companies Act. ${ }^{10}$ To

6 According to Virgos, the concept of CMI was inspired by the 1990 Istanbul Convention on Certain International Aspects of Bankruptcy (Council of Europe), which in turn tried to develop the idea of Article 3 of the EEC 1982 Draft Convention (M. VIRGos, "The 1995 European Community Convention on Insolvency Proceedings : an Insider's View", Forum internationale, n 25, 1998, The Hague, Kluwer, at p. 13, § 25).

7 M. BALZ, "The European Union Convention on Insolvency Proceedings (International Law Symposium)", Am. Bankruptcy L. J., 1996, vol. 70/4, 485-531, at p. 504.

$8 \quad$ Decision of Lightman J (High Court, Chancery Division) of 4 July 2002.

9 Although no judgment was delivered, the outline submissions made to the court by Gabriel Moss, QC, acting as lead counsel for the petitioner, are available at www.iiiglobal.org (under the heading European cases). The following elements were underlined in those submissions : $1^{\circ}$ ) The Company's main creditors, EEE and EPOL, knew that the Company was administered from London; the employees were under local management, but would have been aware that local management reported to the director in London and that important human resources issues were dealt with in London; $2^{\circ}$ ) the commercial agents responsible for dealing with customers negotiated their employment agreements with the central legal department in London; $3^{\circ}$ ) the customers dealt with Spanish employees of the Company on a day-to-day basis; $4^{\circ}$ ) all customers (in particular those who were large in size) would have been subject to credit authorisation from London.

10 Re BRAC Rent-A-Car International, Inc., [2003] E.W.H.C. (Ch.) 128; [2003] 2 All. E.R. 201; [2003] 
justify this finding, the court referred to the fact that almost all employees of the company, which was responsible for managing the European, Middle Eastern and African operations of the Budget Group of car rental companies, worked in England, where the chief operating officer with responsibility for the day to day management and control of the company was also based. That the court's order concerned a company incorporated outside the EU was not sufficient to prevent the application of the Regulation. ${ }^{11}$ Although it may have been controversial at first, this principle seems to be almost universally accepted. ${ }^{12}$

After Enron Directo and $B R A C$ many cases followed. It would be impossible and even useless to attempt to summarize them all. ${ }^{13}$ Some of these cases have become famous in the insolvency in crowd. A substantial part of developing case law concerned corporate debtors which were part of a group of companies. This adds an additional dimension to the difficulty of defining with precision the applicable jurisdictional test.

The surprise generated by these first cases and the unexpected results reached by the courts had barely abated that a new development provided Eurosceptic commentators yet more ammunition to criticize the Regulation. This time, the attention focused on the potential conflict that could arise from the opening of insolvency proceedings in one Member State relating to a company incorporated in another Member State. If English courts accept to take jurisdiction over debtors incorporated in other Member States, how would the courts of those Member States react? Given the novelty of the concept and the lack of a clear definition in the Regulation, nothing guaranteed that the interpretation of the COMI favored by English courts would be shared by the courts of other Member States. This raised the possibility of courts concurrently claiming jurisdiction to open insolvency proceedings regarding the same debtor - a worst case scenario which had been predicted by some commentators. ${ }^{14}$

B.C.C. 248 (Lloyd J.). See on this case, the observations of S. KREBBER, "Europäische Insolvenzordnung, Drittstaatengesellschaften, Drittsstaatensachverhalte und innergemeinschaftlichte Konflikte", IPRax, 2004, at p. 540 and B. Wessels, "Privaatrecht Actueel. Rechtspersonen met zetel buiten de EU kunnen onderworpen zijn aan een insolventieprocedure in de EU", W.P.N.R. 2003/6534, at pp. 403-404.

11 In that case, the Creditors' Committee in the US supported BRAC's petition.

12 See e.g. B. Wessels, Internationaal insolventierecht, Series Polak/Wessels, vol. X (2003), at $§ 10405$. Fletcher (above, note 4 , at p. 383 , at $\S 7.63$ ) rightly notes that « If the Regulation could be precluded from having application to a corporate debtor, whose functional base is intended to be located within the Community, by the expedient of arranging that its place of incorporation is outside the Community, the debtor and its assets would escape being subject to the rules and principles of insolvency which are applicable to their immediate competitors $»$.

13 One will find useful information on a large number of cases in the database operated by Cimejes, available at www.eir-database.com. Reports on case law have also been published for most countries. See e.g. G. W. BazINAs, EU Regulation on Insolvency Proceedings: the first year and the outlook from Greece, available at www.iiglobal.org; A. HeidBrink, "Report for Germany", Eur. Comp. L., 2005, 6668; M. Raimon, "Centre des intérêts principaux et coordination des procédures dans la jurisprudence européenne sur le Règlement relatif aux procédures d'insolvabilité », J.D.I., 2005, 739-762; C. Tomasetti and M. Schiliro, « Report from Italy », Eur. Comp. L., 2005, 69-71; J. Vrancken Peeters, « Report from the Netherlands", Eur. Comp. L., 2005, 71-73; C. Rossel, "Report from Spain”, Eur. Comp. L., 2005, 73-76; A. Videon and J. McCABE, "Report from the United Kingdom", Eur. Comp. L., 2005, 76-82; S. BARIATTI, "L'applicazione del regolamento n. 1346/2000 nella giurisprudenza", Rivista di diritto processuale, 2005, 673-700. For Belgium see our report published in Droit des affaires/Ondernemingsrecht, 2005, 301-319.

14 See e.g. G. Moss (above, note 5), at p. 171, § 8.47. 
If one looks back at the first few years of application of the Regulation, the existing case law indeed gives the impression of a concert of discordant voices. Some courts have arguably taken a more flexible approach than other courts when construing the proper meaning of the COMI. This is certainly not unique to the Insolvency Regulation. Other European rules have also been plagued by divergences in application. ${ }^{15}$ As with the Brussels I Regulation, these differences have created some tensions between courts. Unlike under the Brussels I Regulation, the Insolvency Regulation does not, however, offer a clear and crisp solution to parallel proceedings. There is no equivalent to the guillotine-like lis alibi pendens rule to be found in Article 27 of the Brussels I Regulation. Although in theory Article 16 of the Regulation offers a mechanisms to solve concurrent claims of jurisdiction, in some cases this mechanism failed to prevent contradicting outcomes. This happened in the ISA-Daisytek insolvency and, to a much lesser extent, in the Rover case.

Daisytek was a group based in the US with European subsidiaries, controlled by a UK holding company, Daisytek-ISA Ltd. The ultimate parent company, Daisytek Inc. was placed under Chapter 11 in May 2003. Shortly thereafter, the directors of the English holding petitioned the courts of England to place the English subsidiaries under administration. The petition also included the French and German subsidiaries. On 16 May 2003, the High Court of Leeds granted the petition. ${ }^{16}$

Looking at each subsidiary separately, the Court reviewed the concept of COMI and found that even though the French and German subsidiaries conducted their businesses from their premises in France and Germany, the parent company in England exercised such a high level of control on the activities of the subsidiaries that their COMI could not but be located in England.

The court was particularly influenced by the following elements, which it used to conclude that the subsidiaries conducted the administration of their interests on a regular basis in England :

- the fact that the financial functions of the subsidiaries were performed by the headquarters, through a factoring agreement concluded with an English subsidiary of the Royal Bank of Scotland;

- the fact that the financial information was compiled in accordance with the English requirements;

- the fact that the subsidiaries could not make purchase above a certain amount without approval of the headquarters;

- the fact that all senior employees of the German subsidiaries were recruited after consultation with the headquarters;

15 It is enough to refer to the long standing controversy on the possibility for a court of a Member State to decline the jurisdiction granted by the Regulation 44/2001. The ECJ finally settled this point in the Owusu case, after years of uncertainty (ECJ, Grand Chamber, 1 March 2005, Andrew Owusu v. N.B. Jackson, trading as 'Villa Holidays Bal-Inn Villas' and others, case C-281-02, note yet published in ECR).

16 Re Daisytek-ISA Ltd. and others, claims nos 861-876 of 2003 [2003] BCC 562; [2004] B.P.I.R. 30 (16 may 2003, Chancery Division, Leeds). The decision has also been published in JOR 2003/287 (with comments by B. Wessels) and in ZIP, 2003, 1362. 
- the fact that all information technology and support was being done by the headquarters;

- the fact that over $70 \%$ of the purchases were negotiated and dealt with by the headquarters;

- finally, the fact that the corporate entity and branding was run by the headquarters.

Drawing on this first conclusion, the Court then turned to the other key element of the test, i.e. the question whether the place where the debtor conducts his business is ascertainable by third parties. In its judgment the court put special emphasis on the expectations of the group's financiers and trade suppliers, which it deemed to be the "most important group of potential creditors". It appeared that the German subsidiaries were financed by a factoring agreement which had been arranged for them by the headquarters and that over $70 \%$ of the goods were supplied to them under contracts made by the headquarters in England. The Court concluded that a large majority of potential creditors regarded England as the place where the most important functions of the foreign subsidiaries were carried out.

Accordingly, the Court was satisfied that the presumption under Article 3(1) to the effect that the COMI of a company is at the place of its registered office had been convincingly rebutted.

The opening of insolvency proceedings in England did not go unnoticed in France where the directors of the French subsidiary ISA-Daisytek SAS requested on 23 May 2003 the opening of a 'procédure de redressement judiciaire'.${ }^{17}$ This was obviously only possible if the French court found that the COMI was in France. Under Article 27 of the Regulation, secondary proceedings could indeed only be winding up proceedings. The tribunal de commerce of Cergy-Pontoise held that the French subsidiary could not be seen as an establishment in the sense of Article 3(2). It also held that the English decision should be denied recognition in France as the decision amounted to a denial of the separate corporate personality of the French subsidiary. ${ }^{18}$ The decision has rightly been criticized

$17 \quad$ In Germany, the Amtsgericht of Düsseldorf at first reacted similarly and granted the petition of a local German creditor of one of the subsidiairies to open insolvency proceedings (AG Düsseldorf, 6 June 2003, ZIP 30/2003, at p. 1363). This decision was, however, revised thereafter by the same court (AG Düsseldorf, 12 March 2004, IPRax, 2004, 431; ZIP, 2004, 623). The latter judgment has been upheld in appeal (OLG Düsseldorf, 9 July 2004, $R I W, 2005$, 150), the court finding that the English judgment should be granted recognition in Germany. The reaction in the literature has been quite hostile. Both paulus $(E W i R, 2003$ at p. 709) and Mankowski (EWiR, 2003 at p.1767) have strongly criticized what they called the remarkably broad interpretation of the COMI by English courts.

18 The case was even brought to the attention of the French Parliament, one MP referred a question to the Garde des Sceaux on the proper interpretation of the COMI : question nr. 40288 by Ms. Gruny, published in the Journal Officiel, 1 June 2004, at p. 3957. In his answer (published in the Journal Officiel, 3 August 2004, at p. 6104) the Minister explained that "sous réserve de l'interprétation souveraine des cours et tribunaux, il n'est pas contestable que le règlement 1346/2000 du 29 mai 2000, relatif aux procédures d'insolvabilité, n'a pas pour objet de résoudre les difficultés nées de l'insolvabilité de groupes internationaux de sociétés. Tel que le précise son troisième considérant, il est établi pour coordonner les mesures à prendre à l'égard du patrimoine d'un débiteur insolvable, les activités des entreprises ayant de plus en plus souvent des effets transfrontaliers. La décision de la cour d'appel de Versailles, en date du 16 mai 2003, dont il convient de remarquer qu'elle a fait l'objet d'un pourvoi en cassation de la part du ministère public, ne remet pas en cause ce principe. Elle se fonde sur le critère de compétence reconnu par le règlement. Ce critère est le centre des intérêts principaux du débiteur, présumé, en droit français, pour une personne morale, être son siège 
on the issue of recognition. ${ }^{19}$ As expected it was revised in appeal, the Court of Appeals of Versailles holding that the decision of Justice McGonigal should have been afforded recognition in France..$^{20}$ The Cour de cassation has recently refused to overtun the Court of Appeal's decision. ${ }^{21}$

The Rover case proceeded along similar lines. As is well known, Rover was active in the automobile industry. The group which had reached the last stage of a long decline, operated on the continent through several national subsidiaries. In April 2005, Judge Norris of the Chancery Division, High Court (Birmingham) accepted applications for administration orders made by the directors of 8 national subsidiaries part of the $\mathrm{MG}$ Rover Group, which operated as national sales companies supplying the cars of the MG Rover Group to local distributors. ${ }^{22}$ Upon reviewing the evidence submitted by the ,joint administrators of companies within the Rover Group already under administration, the court was satisfied that the COMI of the national sales companies was located in England. Unlike in the Daisytek case, the judge did not consider each of the national subsidiaries separately but proceeded to outline the main factors which in his view justified his conclusion. These elements coincided broadly with those already outlined in the Daisytek decision : the overall control exercised in England on the management of each of the subsidiary (including on the appointment and removal of senior employees), the absence of any autonomy in budget setting, financial scrutiny and funding, the absence of any independent trading by the subsidiaries, which functioned as mere gateways through which cars were sold from England to the local markets, the fact that the parent company in England was the main creditor and main supplier of the subsidiaries, the fact that creditors would look to England for the satisfaction of their

statutaire et non l'appartenance à un groupe. Il importe, dès lors, que le juge, pour reconnaître ce critère, se prononce sur le lieu effectif de localisation du centre principal des intérêts de la personne morale et qu'il recherche si les tiers pouvaient en avoir connaissance. Retenir systématiquement que le centre principal des intérêts d'une société filiale serait le lieu où est établie sa société mère serait un détournement du texte communautaire. Ce détournement serait de nature à porter atteinte à l'ordre public, notamment en ce que les représentants du personnel de la personne morale concernée ne seraient pas entendus préalablement à l'ouverture de la procédure ».

19 Рн. Hameau and M. Raimon, "International insolvencies. The European Approach", I.B.L.J., 2003, (645), 660-661.

20 Versailles, 4 September 2003, D., 2003, 2352 (with comments by J.-L. VAllens); Rev. crit. dr. int. priv., 2003, 667 (with comments by G. KhaIrallah); J.D.I., 2004, 142 (with comments by A. J ACQUEMONT); JCP 2006, 10147 (with comments by M. MenJuCQ); JOR, 2003/288; R.D.C.,2004, 820 (with comments by C. BArBé). English translation sub nom. Klempka v. ISA Daisytek SA [2003] B.C.C. 984. Unfortunately, before reviewing the effect of Article 16 of the Insolvency Regulation and the obligation it imposed on French court to give effect to the decision of the English court, the Court of Appeal summarized the reasoning used by the court of Leeds to justify its claim of jurisdiction. By doing so, the Court of Appeal appeared to verify whether the court of Leeds could indeed claim jurisdiction over the French subsidiary. Likewise, in the Rover case, the commercial court of Nanterre only accepted to give effect to the English judgment which had opened administration proceedings in relation to a French subsidiary of the group after having first noted with approval the reasoning followed by the English court to find that the subsidiary's COMI was located in England. This may have been only an obiter dictum (as noted by R. Damman, D., 2005, at p. 1791). It is, however, submitted that such considerations have no place in a dispute concerning the proper effect to be given to a foreign judgment under Article 16 of the Regulation.

21 Court of Cassation, 27 June 2006, D., 2006, A.J. at p. 1816; Gaz. Pal., 14 July 2006 at p. 7 (and the comments by R. Dammann and G. Podeur in Banque \& Droit, 2006/109 at pp. 3-8).

22 The subsidiaries concerned were : MG Rover Deutschland, MG Rover Nederland, MG Rover Group Benelux, MG Rover Espana, MG Rover Italia, MG Rover Portugal, MG Rover France and Rover Ireland Ltd. 
claims and finally the overall consideration that the local subsidiaries formed part of a network held together by their relationship with the MG Group.

Unlike in the Daisytek case, courts on the continent did not felt threatened by the opening of administration proceedings in England. In fact, the French court rightly pointed to Article 16 and the obligation it imposed to recognize the decision of the English court. The French court even refused to hold that this decision was in breach of public policy. ${ }^{23}$ The resistance, if any, to the consolidation of insolvency proceedings over the group in England, took a more subtle form. In some countries, creditors succeeded in opening secondary proceedings in respect of the local subsidiary, thereby increasing their leverage in the discussions with the administrators of the group. ${ }^{24}$

As these cases show, in the absence of a clear mechanism to solve jurisdictional disputes, the weight rests upon the rules on recognition. Since the Regulation has adopted the European principle of automatic recognition and since a debtor cannot have more than one COMI, the court which first opens proceedings can claim priority. This only adds an extra pressure on the definition of the COMI.

The most famous case where a conflict arose is certainly the Eurofood case. As is well known, this case arose out of the Parmalat debacle. Eurofood was an Irish subsidiary of the Parmalat empire. It served as a special purpose vehicle for large financial transactions.

In January 2004, a creditor of Eurofood presented a petition to Ireland's High Court for the winding up of Eurofood and the appointment of a provisional liquidator. ${ }^{25}$ On that same day, a provisional liquidator was appointed. ${ }^{26}$ In February 2004, the Italian Ministry for Productive Activities admitted Eurofood to an Italian extraordinary administration proceeding similar to that of Parmalat. Following this decision, the Court of Parma declared Eurofood insolvent and found that Eurofood's COMI was in Italy. In March of the same year, the matter came back to the Irish High Court. ${ }^{27}$ Even though the court noted in its judgment that it was anxious to avoid a conflict of jurisdiction, it refused recognition to the decision of the Parma court based on Article 26 of the Regulation. ${ }^{28}$ The High

23 T. com. Nanterre, 19 May 2005, D., 2005, Jur. 1787 (with comments R. Damman); JCP 2005, II, 10116 (with comments M. MenuucQ) and Versailles, 15 December 2005, D. 2006, AJ, 142 (with comments by A. Lienhard) and D. 2006, Jur., 379 (with comments by R. DAMman).

24 Secondary proceedings were opened in relation to the Dutch subsidiary, MG Rover Netherlands B.V.

25 The creditor was the Bank of America. The Bank of America was not only a creditor but also managed the corporate housekeeping of Eurofood by virtue of an agreement concluded with Parmalat.

26 In the matter of Eurofood IFSC Ltd. and in the matter of The Companies Acts $1963-2003$, High Court, Judgment of 27 January 2004.

27 In the matter of Eurofood IFSC Ltd. and in the matter of The Companies Acts 1963 - 2003, High Court (Mr. Justice Kelly), judgment of 23 March 2004 (also published in JOR, 2004/211, with comments by P.M. Veder) and in ZIP, 2004, 1223.

28 Article 26 allows a member state to refuse to recognize insolvency proceedings opened in another state or to enforce a judgment handed down in the context of such proceedings where the effects of such recognition or enforcement would be manifestly contrary to the state's public policy and, in particular, its fundamental principles or the constitutional rights and liberties of the individual. According to the High Court, the proceedings before the Parma court violated the Eurofood creditors' right to a fair hearing because the Eurofood creditors were not heard on the application before the Parma court, despite the directive from the Parma court that all interested parties be heard. The High Court further found that there was a breach of due process before the Parma court because the 
Court further found that the clear perception of the Eurofood's creditors was that they were dealing with a company located in Ireland and subject to Irish fiscal and regulatory provisions. Accordingly, the Court found that Eurofood's COMI was in Ireland and that the winding up proceedings constituted main insolvency proceedings. The Irish Supreme Court referred the dispute to the European Court of Justice. ${ }^{29}$

The dispute was provisionally settled by the Court of Justice's ruling, ${ }^{30}$ which, as has been said, "came down firmly on the side of the Irish courts". ${ }^{1}$

The preceding overview has shown that the COMI has given rise to substantial discussions. In what follows, I will attempt to give some guidance on how to construe the concept, based on the experience in the courts of Member States, paying particular attention to the recent ruling of the ECJ in the Eurofood case. I will review the lessons that one can draw from the cases published so far, starting from the more obvious one and moving to the most difficult and controversial ones.

\section{Lesson 1 : Most cases do not give rise to difficulties}

In most cases, identifying the COMI of the corporate debtor will not prove an insurmountable task. Without the benefit of any scientific data, one can venture that in more than $90 \%$ of insolvencies opened in Europe, there should be no doubt on the location of the COMI of the debtor. This number probably goes down substantially if one only considers debtors which are part of a corporate group. Nevertheless, on average, the jurisdiction test to be found in Article 3(1) of the Regulation can be applied easily, even effortlessly.

It is important to keep this in mind because the law as it exists today and in particular the variety of cases and decisions could give the impression that the European law of insolvency is in a state of chaos. Some have even argued that the Regulation has failed to reach its goals. ${ }^{32}$ This needs to be nuanced. Even if the jurisdictional test laid down in Article 3(1) of the Regulation has given rise to some controversies, the Regulation is by any measure a splendid success which non European countries should envy. This holds true for the jurisdictional test but also more generally for the whole scheme put in place by the Regulation. By all accounts, this scheme is well thought and represents a workable

provisional liquidator of Eurofood had been notified at a very late stage (actually, after close of business on a Friday) of the hearing that took place in Parma and that the petition or relevant documents had not been handed to him in time.

29 Irish Supreme Court, 27 July 2004, JOR, 287 (also published in ZIP, 2004, 1969). The Supreme Court referred 5 questions to the ECJ, the most important of which read as follows : "Where, a. the registered offices of a parent company and its subsidiary are in two different member states, $b$. the subsidiary conducts the administration of its interests on a regular basis in a manner ascertainable by third parties and in complete and regular respect for its own corporate identity in the member state where its registered office is situated and c. the parent company is in a position, by virtue of its shareholding and power to appoint directors, to control and does in fact control the policy of the subsidiary, in determining the "centre of main interests", are the governing factors those referred to at b) above or on the other hand those referred to at c) above?"

30 ECJ, 2 May 2006, Eurofood ISFC Ltd., case C-341/04.

31 J. Cole and J. Tillman, « At last, some answers on insolvency jurisdiction », ILFR, June 2006, 9.

32 A. P. G. Gielen, «Is de Insolventieverordening haar doel voorbijgestreefd? Van forumshopping en rechtsonzekerheid in de Europese insolventiepraktijk », O \& F, 2004, at pp. 78-84. 
compromise which furthers the interests of creditors without unnecessarily limiting the debtor's position. It is true that the Regulation can be perfected in several respects. To take but one example, the rules laid out by the Regulation for cooperation between administrators are at best rudimentary and should certainly be complemented by practical guidelines. ${ }^{33}$ This need not, however, put in doubt the value of the Regulation as a whole and of its jurisdictional rules in particular.

\section{Lesson 2 : The importance and difficulty of an autonomous interpretation}

Another lesson that can easily be drawn from the experience so far with the Regulation is the importance of achieving the highest possible degree of convergence between Member States on the interpretation of the concept of 'Center of the Main Interests'. This speaks for itself since the value of the Regulation would be greatly diminished if its provisions and Article 3(1) is certainly the key one - were to be construed differently in the various European jurisdictions.

The ECJ has stressed this need in the Eurofood case, where it held that « The concept of the centre of main interests is peculiar to the Regulation. Therefore, it has an autonomous meaning and must therefore be interpreted in a uniform way, independently of national legislation $\gg{ }^{34}$

In this respect, it is important to stress that, contrary to 'popular' belief, no one country has the privilege of a 'deviant' or 'overbroad' reading of the COMI. It is true that English courts have been the most creative so far. It has become common to refer to London as the 'Insolvency capital of Europe'. ${ }^{35}$ This is probably the result of the peculiarities of English insolvency law, which is highly creditors driven and where courts have lend a sympathetic ear to the request by creditors wishing to pursue consolidated insolvency proceedings.

However, other countries have, after some hesitation, followed suit. Nowadays, courts in most Member States have realized the importance of adopting an open interpretation of the COMI and to look beyond the presumption in favor of the statutory seat. German courts have for example opened insolvency proceedings in relation to companies incorporated in Austria. ${ }^{36}$ In Italy, a court decided in the Cirio del Monte case that a Dutch subsidiary had its center of main interests in Rome. French courts have also started to engineer pan-European recovery attempts covering companies incorporated in other Member States- a trend which may have been sparked by the recent revision of French

33 On this issue, see our observations in "De rol van de curator in grensoverschrijdende insolventies" which appeared in Curatoren en vereffenaars : actuele ontwikkelingen, H. Cousy et al. (ed.), Intersentia, 2006, 823-846.

34 ECJ, 2 May 2006, Eurofood ISFC Ltd., case C-341/04, at $§ 31$.

35 J. Willcock, "How Europe Became the Capital of Forum Shopping (and How London Hopes to Become the Delaware of Europe)", INSOL World, 2003, 8-9.

36 See the Hettlage case decided by the court in Munich: Hettlage AG \& Co. KG, an Austrian company, $100 \%$ subsidiary of the German Hettlage KgaA, has been made subject to German insolvency proceedings : LG München, 4 May 2004, ZIP, 2004, 962; see also the Hulka-Werke case where the court of Offenburg likewise opened insolvency proceedings concerning the Austrian subsidiary of a German group (AG Offenburg, 2 August 2004, reported by K. Pannen and S. Riedemann, EWiR, Art. 3 EuInsVO 1/05, at p. 74). 
insolvency law. In the Emtec case, the Commercial Court of Nanterre of was prepared to accept, after reviewing in great details the factual situation of a subsidiary incorporated in Belgium, that its COMI was located in France. ${ }^{37}$ In the recent Eurotunnel case, the Commercial Court of Paris opened insolvency proceedings in relation to not less than 17 companies, some of which has been incorporated in England, Belgium, Germany and the Netherlands, after finding that the COMI of all these companies was located in Paris. ${ }^{38}$

Comparative observation of the case law of various Member states thus reveals a common trend and indicates that most courts have abandoned the literal reading of Article 3(1) of the Regulation, which would make it impossible to take into account the relationship existing between a corporate debtor and the group of companies to which it belongs. ${ }^{39}$ The task that lies ahead is to single out the common factors shared by the courts of all Member States in order to elaborate a truly European reading of the COMI.

\section{Lesson 3 : The limited impact of the statutory seat and of the presumption of Article 3(1)}

Article 3(1) of the Regulation provides that for corporations, the center of the main interests is presumed to be located at the registered office. Analysis of the case law reveals that courts have not been shy in accepting evidence rebutting this presumption. At the very least, the presumption has not been given the weight expected by the drafters of the Regulation.

One could even go further and wonder whether in the post Centros world in which we live, it is still justified to give any credit to the statutory seat or to the place of the registered office as a decisive factor in locating a company's center of gravity. The intense corporate migration witnessed post-Centros means that this factor should in my view be accorded little credit, if any at all. The rulings of the ECJ in the famous Centros, Überseering and Inspire Art cases have given a tremendous boost to such migration, creating countless situations where the presumption is of no value. By one account, more than 17.000 German businesses had emigrated to England to take the form of a Ltd. company in $2004 .{ }^{40}$ In a recent study, it was shown that incorporations of private limited companies in England by foreign administrators had increased by more than $500 \% .{ }^{41}$

One can therefore ask whether the presumption brings any advantage in terms of increased legal certainty. In the system contemplated by the drafters of the Regulation, a creditor could rely on the statutory seat as a strong indicator of which jurisdiction would take the lead in opening insolvency proceedings. Parties relying on the presumption could wait until the debtor or anyone else succeeded in convincing the court that the

37 T. com. Nanterre, 25 February 2006, D., 2006, Jur., 793 (with comments by J.-L. ValLENS).

38 Commercial Court of Paris, 2 August 2006, D., 2006, Jur., 2329 (with comments by R. Damman and G. Podeur).

39 In the literature on can, however, still find some voices pleading for a literal reading og Article 3. See e.g. N. CASTell, "Application du Règlement CE 1346/2000 relatif aux procédures d'insolvabilité », D., 2006, pp. 306-311 at p. 310, §§ 9 and 10.

40 «Pan European Companies. Limited Appeal”, The Economist, 17 September 2005, 69, with reference to the services offered by 'Go Ahead Ltd.'

41 M. Becht, C. Mayer et H. F. Wagner, « Corporate mobility and the costs of regulation », European Corporate Governance Institute, Law Working Paper n 70/2006, 53 p. 
presumption did not match reality. As indicated in the Virgos-Schmit Report, the rationale for the presumption was that the registered office "normally corresponds to the debtor's head office", ${ }^{42}$

As the number of companies exercising their trade in another jurisdiction than the one of their incorporation (the so-called 'Scheinauslandgesellschaften' or pseudo-foreign corporations) arises, the presumption, however, offers a false sense of certainty. The value of the presumption declines even more with the broad reading given to the COMI by most courts.

Hence, the value of the presumption may rightly be questioned. In another context, the Commission has suggested deleting the presumption which helped determine the law applicable to contracts in the absence of choice of law by the parties. ${ }^{43}$ In our view, deleting the presumption will clarify the debate. At the very least it will help avoid controversies on the question which degree of proof is required in order to overcome the presumption. $^{44}$

\section{Lesson 4 : Letterbox companies are an easy case}

Another lesson that can be drawn from the existing case law is that so-called letterbox companies offer an easy case. It should be generally accepted that such companies cannot claim any right to be subject to the jurisdiction of the country of their incorporation. ${ }^{45}$

Courts in all countries have had no hesitation to open insolvency proceedings relating to foreign 'letterbox' companies. In the Interexx case the Hague Court of Appeal opened insolvency proceedings regarding Interexx Enterprises Ltd., which had its registered office in the UK. ${ }^{46}$ The Court found that the key management personnel of the company (i.e. the director and the company secretary) lived in the Netherlands and that the company was registered in the Company Registry as an 'extra-territorial' corporation. Liwekise, the Commercial Court of Brussels has on several occasions opened main

$42 \quad$ Virgos-Schmit Report at $\S 75$.

43 The presumption can be found in Article 4(2) of the 1980 Rome Convention. The Commission's proposal was made in its Proposal for a Regulation on the law applicable to contractual obligations (Com (2005) 650 final).

44 A question which is not addressed by the Regulation, as professor Fletcher had already noticed in 1997 (in respect of the defunct Convention) : I. FLETCHER, "The EU Convention on Insolvency Proceedings : An Overview and Comment, with U.S. Interest in Mind”, Brooklyn J. Int'l Law 1997, (25), 37.

45 This was already indicated by Virgos in his early commentary of the 1995 Insolvency Convention (M. VIRGOS, above note 6 , at p. $13, \S 25:$ : In the case of mailbox firms, the presumption will conduct to the firm's real headquarters »).

46 The Hague, 8 April 2003, Interrexx Enterprises Ltd/MBI Beton A.J. van der Meijden B.V., docket $\mathrm{n}^{\circ}$ R03/132, not published, commented upon by R.C. van Wieringhen Borski and J.F. Ouwehand, "De Europese Insolventieverordening onderweg naar Luxemburg", TvI, 2004, nr. 62, p. 309 and by B. Wessels, "International Jurisdiction to Open Insolvency Proceedings in Europe, in particular against (groups of ) companies", Institute for Law \& Finance Working Paper n 17, at p. 13.. 
proceedings in relation to companies incorporated in England ${ }^{47}$ or Greece. ${ }^{48}$ Similar decisions can be found in Luxembourg, in respect of companies incorporated in France ${ }^{49}$ and German courts in respect of companies incorporated in England. ${ }^{50}$

The ECJ has incidentally approved this case law in its Eurofood ruling in which it held that the presumption in favor of the statutory seat can be rebutted " in particular in the case of a 'letterbox' company not carrying out any business in the territory of the Member State in which its registered office is situated $» .^{51}$

It should not come as a surprise that English companies are the first 'victim' of the COMI and of its unalterable grounding in the economic reality. As is well known, incorporation in England is considerably easier and cheaper than on most continental European countries. By providing a possibility for the Member State where the company exercises its trade, to claim jurisdiction in insolvency matters, the European Insolvency Regulation should be seen as a welcome complement to the radical liberalization of the corporate landscape brought about by the ECJ's case law. ${ }^{52}$

\section{Lesson 5: The fact that a debtor is part of a group of companies is as such not relevant}

Much has been written on the impact of the Regulation on groups of companies. The drafters of the Regulation purposefully avoided to include specific rules for parentsubsidiary relationships in the Regulation ${ }^{53}$ in view of the fact that the Member States had widely divergent views on the legal consequences of the parent-subsidiary relationships.

Nevertheless, insolvencies of groups have proven to be one of main and thorniest issues in the application of the Regulation. In many cases decided by courts, in particular by English courts, application was made to open insolvency proceedings over a group of companies or at least over a group of corporate entities with strong interrelationships. Courts have indubitably been influenced by the group factor and have referred to some

47 E.g. the CGC Communications Ltd. case (Commercial Court of Brussels, 29 July 2003, D.A.O.R., 2003, 68) : the court accepts to open insolvency proceedings, as requested by the public prosecutor, regarding a company incorporated in England. It appeared that the company had no activity whatsoever in England.

48 Commercial Court of Brussels, 2 October 2003 (Electra Airlines), available at www. eirdatabase.com.

49 Trib. arr. Luxemburg, 15 April 2005 (Silvalux s.a.r.l.), available at www. eir-database.com.

50 See e.g. AG Hamburg, 14 May 2003, ZIP, 2003, at p. 1008 (with comments by J. Schmidt) and EWiR, 2003 at p. 925.

51 ECJ, 2 May 2006, case C-341/04 at $§ 35$.

52 For an overview of the practical consequences see D. Griffiths and F. Tschentscher, « The Straw Dogs of Europe », Insol. Intell., 2004 at pp. 57-61. See also M. LAuterfeld, “'Centros' and the EC Regulation on Insolvency Proceedings : the End of the 'Real Seat' Approach Towards PseudoForeign Companies in German International Company and Insolvency Law? The Danger of Diverging Developments of the Connecting Factors in Company and Insolvency Law", Eur. Business Law Rev., 2001, 79-88.

53 See on this point M. BALz (above, note 7) at p. 503. In the Virgos Schmit Report, one can read that "This Convention offers no rule for groups of affiliated companies (parent-subsidiary schemes)" (Report Virgos-Schmit, § 76.1). 
characteristics of the group of companies to identify the COMI of a company part of such a group. In some of these cases, courts have even succeeded in consolidating insolvency proceedings over the whole group.

It is submitted that under the Regulation the mere fact that a company is part of a group should not be taken into account as a decisive factor to identify the COMI. Incidentally, the Court of Appeal of Versailles in the Daisytek case has confirmed this view : after reviewing the reasoning followed by the court of Leeds to open insolvency proceedings on a French subsidiary, the court concluded that "it is therefore untrue to argue that the High Court of Leeds took into consideration the notions of establishment, group of companies or subsidiary $\gg .{ }^{54}$

The 'group' factor should be, as such, discounted because, in the first place, it is misleading to think that all groups of companies are structured along the same lines. ${ }^{55}$ When one looks at the reality of groups of companies, one cannot but recognize the existence of a surprising variety. Leaving aside the special position of horizontally integrated groups, experience shows that some groups may be strongly integrated, with the business of all companies conducted (carelessly or as a strategy) as if it was a single entity. In that case, it will be more difficult for outsiders to unravel the group's legal structure. The event of insolvency in this type of groups may concern all or almost all the affiliate companies as they will all face insolvency simultaneously. Conversely, some companies could form a group and still operate in a more separate mode, with each company organized within national borders and functioning in accordance with national regimes. ${ }^{56}$

Another reason, probably as important as the first one if not more, is that third parties, and in particular the creditors, may not be aware of the group's internal structure. As defined by the ECJ, the COMI should be identified by reference to criteria that are both objective and ascertainable by third parties. ${ }^{57}$ In Eurofood, the creditor which requested the opening of insolvency proceedings in Ireland, was not an ordinary creditor. It conducted the day to day administration of Eurofood under the terms of an administration agreement concluded with Parmalat. As such Bank of America had access to information that 'ordinary' creditors may not have. Similarly, major creditors such as credit institutions who have lent the debtor large amounts of money, will have prime access to their debtor's corporate structure. This may not be the case for an 'ordinary' supplier of office furniture or an employee. It may indeed be difficult for such 'ordinary'

$54 \quad$ The original text reads as follows : «Il est donc inexact de prétendre que la Haute Cour de Justice de Leeds se serait fondée sur la notion d'établissement, ou encore sur la notion de groupe de sociétés et de filiale » (Versailles, 4 September 2003, D., 2003, 235).

55 Consider in this respect the observations made by R. VAN GALEN (« The European Insolvency Regulation and Group of Companies "), TvI, 2004, (57) at p. 58-59

56 See for more details on this P. I. Blumberg, The Law of Corporate Groups: Procedural Problems in the Law of Parent and Subsidiary Corporations (Boston, Little Brown, 1983, Supp 1992), pp. $432-$ 438. Blumberg classifies corporate groups into strongly integrated groups, weakly integrated groups, conglomerate groups, and investment companies depending on the extent of interrelationship of organization, market and public posture. He considers various factors to draw his classification. Among other elements, Mr Blumberg refers to the following : (a) financial interdependence; (b) economic integration; (c) participation by the parent in the decision making of the constituents; and (d) holding out of the group to the public as a single integrated enterprise.

57 ECJ, 2 May 2006, case C-341/04 at $\S 33$. 
creditors to identify the group's structure and to draw from this structure elements useful in identifying the COMI of one subsidiary.

These reasons and other militate in favor of an approach under which companies are first examined as single legal entity. This has been at least partially confirmed by the ECJ in its Eurofood ruling, where the Court held that « the mere fact that its [the subsidiary] economic choices are or can be controlled by a parent company in another Member State is not enough to rebut the presumption laid down by the Regulation $» .^{58}$ The Court was referring to a subsidiary which carries out some business in the territory of the Member State where its registered office is located, by contrast with the letterbox company. The Court also held that " in the system established by the Regulation for determining the competence of the courts of the Member States, each debtor constituting a distinct legal entity is subject to its own court jurisdiction $»{ }^{59}$ In essence, the Court's ruling must be seen as a warning to courts in Member States that they may not rely on the 'group factor' as a decisive factor.

In fact, contrary to what some have argued, most courts have until now refrained from using the fact that a debtor is part of a group of companies as a license to consider that its COMI is located at the ultimate parent company's COMI. The Daisytek ruling provides a good example. Although it ended up by claiming jurisdiction over German and French subsidiaries of an English company, the Court in Leeds did not simply rely in its decision on the fact that these subsidiaries belonged to one group. Rather, the court discussed an impressive list of factors (which have already been outlined) to justify its findings on jurisdiction. A similar approach was adopted by the Commercial Court of Paris in its Eurotunnel decision. Rather than looking at the corporate structure, the court focused on the degree of control exercised by the the French company on the various entities of the group. ${ }^{60}$

\section{Lesson 6: Efficiency considerations and cost-savings concern should not influence the jurisdiction question}

Building up on the preceding lesson, one may wonder whether courts should take into consideration, when reviewing their jurisdiction under Article 3(1), efficiency concerns or perspectives of a better realization of assets that could arise if some or all subsidiaries of a group are placed under control of the same administrator or at least if the various insolvency proceedings are coordinated by the same court.

It cannot be denied that such coordination of proceedings over the various corporate entities of the same group can produce substantial economies of scale and dramatically improve the chances of a global recovery. In some cases, it can be vital to the interests of the creditors. The insolvency of KPNQwest N.V. provides a topical example : the various subsidiaries of the KPNQwest each owned telecommunication infrastructure in different

58 ECJ, 2 May 2006, case C-341/04 at $\S 36$.

59 ECJ, 2 May 2006, case C-341/04 at $\$ 30$.

60 The court actually noted that «l'article 3 du règlement européen 1346/2000 du 29 mai 2000 n'envisage pas l'hypothèse des groupes de sociétés dont les entreprises seraient établies dans plusieurs Etats de l'Union européenne; qu'il conduit à examiner le sort de chaque entité du groupe prise séparément » (D., 2006, 2330). 
European countries. Taken apart, each company was worth much less than if all companies could be sold together, since the infrastructure owned by each subsidiary had been designed and build to fit in the larger scheme of the group. ${ }^{61}$ This explains why in some countries, provisions are made for what is called substantive consolidation of insolvency proceedings. ${ }^{62}$

Tempting as it may be, such considerations have no place under the Insolvency Regulation. As the Court of Justice has made clear, the Regulation starts from the premise that each corporate debtor must be examined as a single entity. The court may come to the conclusion that the control exercised by a parent company over a subsidiary is so strong that it justifies finding that the subsidiary's COMI coincides with that of the parent. This result may, however, only be justified after a detailed examination of the practical circumstances of each case. Drawing on the efficiency considerations that could follow from consolidated insolvency proceedings would unduly influence the finding on jurisdiction and give too great an incentive to the court to find that the subsidiary's COMI is indeed located at the parent's headquarters. ${ }^{63}$

In this respect, one must question the opportunity of the reference made by several courts to efficiency considerations when addressing the question of the location of a subsidiary's COMI. In the Rover case, the court held that

«The objective of the administration is to secure a better realization of the assets of the national sales companies than would be achieved by an immediate liquidation. It is to co-ordinate and achieve an orderly winding down of stock levels, an orderly collection of book debts and orderly management of warranty claims. Co-ordination and overall control is likely to achieve more for each national sales company than un-coordinated independent action. It is the view of the prospective joint administrators that stock in an administration may achieve as much as sixty per cent of book value, whereas in liquidation it would achieve only thirty five per cent and that book debts may have to be discounted by sixty per cent in an administration but by ninety per cent in a liquidation. $»^{64}$

Even though the court made this statement after having found that it had jurisdiction, when determining whether to make the order, one cannot escape the impression that the impressive numbers put forward by the prospective joint administrators have influenced the court's finding that it had jurisdiction over all national sales companies. This is most unfortunate. ${ }^{65}$ One should indeed avoid creating the impression that a court conveniently

61 In fact, the trustees of the Dutch holding company (KPNQwest N.V.) never succeeded in gaining control on the operations of the other subsidiaries. This explains why the assets were sold for a much lower price than would have been paid if all companies had been sold as a whole.

62 On substantive consolidation in the United States, see R. van GALEN (above note 55) at pp. 63-65. See also P. Henry, "From Atomism to Consolidation in Group's Insolvency", in Internationales Gesellschaftsrecht, vol. 1, P. NoBel (ed.), Bern 1998, 87 ff. and P. Henry, "La faillite consolidée », in Insolvence, désendettement et redressement, B. FoËX and L. THÉVENOz (eds.), Basel, 2000, $221 \mathrm{ff}$.

63 Other commentators give substantial weight to the advantages derived from consolidated proceedings, in particular in the framework of ex ante recovery proceedings. See e.g. R. Dammann, « Droit européen des procédures d'insolvabilité : problématique des conflits de juridiction et de forum shopping », D., 2005, Chr., (1779) at p. 1784.

64 At $\S 21$ of the ruling.

65 See in the same line the considerations of the Commercial Court of Paris in the Eurotunnel case, 
comes to the conclusion that the COMI of several subsidiaries is located in the Member State where the parent company is established so as to allow all proceedings to be consolidated.

In the present state of the law and even though the concept of the COMI is a most flexible one, there is no room for considerations of this kind under the Regulation. The fact that the debtor is a part of a group and that there are potential costs savings if the same office holder is appointed over all of the group companies should not be considered when reviewing the issue of jurisdiction, even if it improves dramatically the chances of a successful group wide restructuring. Once again consideration of third parties' interests justify this reasoning. Indeed, creditors may not be aware of the group structure or even of the fact that their debtor is a subsidiary in a large group. It is even less reasonable to expect that creditors could anticipate on the potential benefits to be derived from a groupwide restructuring. Arguably, this does not hold true for creditors of the whole group or of the ultimate parent company. When reviewing the jurisdiction in respect of one subsidiary, the focus should, however, be on the specific creditors of that subsidiary.

This is not to say that ideally, efficiency concerns should have no place in the determination of jurisdiction over group of companies. It is submitted, however, that if those considerations are to be taken into account, this can only be done on the basis of a new, amended version of the Regulation in which those concerns are explicitly addressed.

The reading suggested here does not mean that the existence of close relationships between companies which belong to the same corporate group, will not and may not influence the localization of the COMI. It remains, however, to be seen how such close relationships may indeed play a role in determining where the COMI lies.

\section{Lesson 7 : The 'Mind of Management' approach}

If the mere fact that a corporate debtor is part of a group of companies and as such is subject to the discipline of the group, is not sufficient to locate the debtor's COMI in the Member State where the parent company is located, what additional circumstances pertaining to the parent-subsidiary relationship could be relevant when determining where the COMI of a subsidiary or any corporation part of a group is located?

One theory has been suggested in this respect, which is known as the 'mind of management' approach. This phrase was apparently crafted by Mr Stephen Taylor. With all due respect, it is submitted that the phrase is ambiguous : catchy as it is, it does not clearly reveal what is exactly intended behind the words. When one looks more closely at its meaning, one could arguably come to different results.

where the court held that «si le règlement européen ne traite pas des groupes de sociétés présentes dans plusieurs Etats membres, désormais nombreux dans l'espace unifié européen, il vise à une administration efficace et homogène de la justice partout où il s'applique; attendu qu'il est d'une bonne administration de la justice de trouver une solution unique à la même difficulté financière qui menace les dix-sept entités requérantes toutes garantes solidaires d'une dette qui excède leur capacité de remboursement » (D., 2006, 2330). 
In a first reading, the mind of management approaches refers to the location where strategic decisions are taken ("where all key decisions concerning the policies, finances and ultimately the fate of the company are taken »). It seems that in Eurofood, the Court of Parma was influenced by considerations of this kind. It took strong account of the fact that Eurofood was wholly owned by Parmalat and that the policy of Eurofood was in fine set by those running Parmalat. In effect, the court referred to the fact that 'real control' over Eurofood was exercised from Italy. It is striking that the court recited in its judgment the various rules of jurisdiction applicable to corporations under Italian private international law and in particular Article 9 of the Italian Bankrupcty Act, which refers to the "principal seat of the undertaking" ${ }^{66}$ The court understood the "principal seat" as being "the centre of direction and organisation of the undertaking itself". ${ }^{67}$ The Court further referred to the fact that "all the choices as to management direction and operative matters were made in Parmalat and that activities at the Irish seat were limited to 'transposing' them slavishly to conform to the local legislation". ${ }^{68}$

It is submitted that in so far as the mind of management approach may be understood as a reference to the 'real seat', this element is too narrow to constitute a valid method to interpret the COMI. This is because, as for the group structure, the 'mind of management' may only be known internally. Where the board of directors meets, who and how strategic decisions are taken, may not be fully transparent to creditors - except the largest ones. Furthermore, as understood in this narrow reading, the mind of management suffers from the same flaws as the 'siège réel' doctrine which is used in some countries to determine the law applicable to corporations. It is well known that it may be very difficult to identify the place where corporate decisions are taken. ${ }^{69}$ This is in particular the case in corporate groups. ${ }^{70}$ In fact, in order to locate with precision the exact place where strategic decisions are taken, one should look beyond the place where corporate organs meet and also consider the role of major shareholders. It is obvious that taken to such extreme interpretation, the mind of management approach cannot prosper.

There is, however, another possible reading of the 'mind of management' approach. In this broad reading, one makes reference to what could be called the 'division of labour' between the various members of the same group of companies. The idea is to examine whether a subsidiary has any practical autonomy on the way its affairs are conducted. ${ }^{71}$

66 Tribunal Civile e Penale di Parma, 19 February 2004, [2004] I.L.Pr 273 at p. 274 (also published in ZIP, 2004, 1220).

67 The Court did no entirely neglect the Regulation's test. It went on to say that as far as third parties were concerned, they could not ignore the fact that Eurofood was a mere vehicle solely designed to serve the financial interests of the Parmalat group. The court noted that most third parties who had dealt with Eurofood were professionals and institutional investors which specific expertise and that « Eurofood's object does not leave any doubt about its ancillary and supporting function in relation to th pursuit of the economic interests of Parmalat SpA and of the other companies in the group » (I.L.Pr. At p. 276).

$68 \quad$ I.L.Pr at p. 277.

69 See in general, S. Rammeloo, Corporations in Private International Law - A European Perspective, OUP, 2001.

70 In Brac Rent-a-Car International Inc. ([2003] 2 All ER 201), Lloyd J. actually observed that the centre of the main interests of a company is not the same as its 'seat' as used e.g. to determine the domicile under the Brussels I Regulation, namely the place where its central management and control abide.

71 It is submitted that the 'division of labour' test is broader than the approach known as the 'headquarter's functions', where one looks at the place where head office functions are carried out. 
This approach has been adopted by a number of courts. As has been explained, the High Court in Leeds adopted a multi-faceted test in the Daisytek case, under which it investigated the relative autonomy enjoyed by each subsidiary on a number of issues such as the budget and financial control, the appointment and removal of key staff members or the contacts and contracts with suppliers and financiers.

In the Daisytek case, the court found that all these elements pointed out in the direction of England as the COMI for the subsidiaries. This reading of the mind of management approach is certainly more sophisticated and broader. As with every multi factor test, it is not easy to apply as it requires a thorough examination of the particular circumstances of each case. As Judge Langan stated in Parkside Flexibles SA., "The identification of a company's centre of main interests involves what would nowadays be called a fact sensitive decision. All relevant material must be weighed up and placed in the balance and the court must then see on which side the scales have come down ». The difficulty must not be underestimated. ${ }^{72}$

In fact, with such reading one comes closer to what has been called the 'command and control' test of COMI. ${ }^{73}$ It is submitted that this test should be the first step of any investigation into the location of a debtor's COMI when the debtor is part of a corporate group. Attention should be paid to the autonomy enjoyed by the subsidiary (in matters such as financial decisions, appointment of staff, management of IT and brand issues, administration of contacts and contracts with local suppliers and customers, etc.) and to the links between the subsidiary and its corporate parent. ${ }^{74} \mathrm{~A}$ finding that the subsidiary enjoys a measure of autonomy, even if relative, should in principle preclude the court from concluding that the subsidiary's COMI coincides with that of the parent company even if considerations of efficiency plead in favor of consolidation of insolvency proceedings.

\section{Lesson 8: One subsidiary is not the other}

When applying the 'command and control' test to the subsidiaries of the same group, it is not excluded that one comes to the conclusion that not all subsidiaries should be afforded the same treatment. Indeed, it is easy to see that in practice, one subsidiary is not the other.

The case law offers contrasting examples which can illustrate this point. In Eurofood, the Irish wholly-owned subsidiary of the Italian Parmalat SpA, was a vehicle used solely to provide financial services to the companies of the Parmalat group. It did not have any

This last approach seems to have been endorsed by G. Moss (in G. Moss, above note 5, at p. 155, § 8.39).

72 One must recognize that civil law jurisdictions are less experienced in dealing with such multi-factor tests. This may explain why some commentators expressed caution about the adoption of such tests, which are associated with a lack of legal certainty (see e.g. J.-L. VALLENS, « Le Règlement européen sur les procédures d'insolvabilité à l'épreuve des groupes de sociétés : l'arbitrage de la CJCE », JCP, E, 2006, n 2071, at p. 1222, § 10).

73 The phrase was coined by Prof. Fletcher (above note 4) at p. 393, § 7.75.

74 As has rightly been suggested, this examination can proceed on the basis of the definition of control offered by IAS Standard 27 issued by the IASB (a suggestion made by R. DAmmAnN (above note 43) at pp. 1784-1785). 
independent economic activities and was used as a mere conduit for financial activities to the benefit of other subsidiaries of the group. In fact, it could apparently have been described as an 'off shore financial division' of Parmalat.

In the EMTEC case, two French companies were the $100 \%$ subsidiaries of a company incorporated in the Netherlands. However, this parent company had no activity of its own. Its only purpose was to serve as a 'tax efficient vehicle' to hold the rights to the corporate brand and to hold the shares in the French operating companies. Obviously, a holding company of this type cannot perform the 'headquarter functions' that in other cases are the privilege of the parent company.

In the Crisscross Telecommunication Group case, the High Court decided on 20 May 2003 to open administration proceedings in relation to 10 different companies located in various EU jurisdiction and in Switzerland. The presumption in favour of the statutory seat was rebutted for each company. In this case, the COMI of all companies was found to be not where the group parent company was located, but in England where one of the subsidiaries was registered and where the "headquarter" activities took place.

These examples show that there is certainly no room under the Regulation to adopt a 'one size fits all'-test to determine the jurisdiction of the court in respect of corporate debtors part of a group of companies. Hence, it could be that even though various companies belong to the same group, the courts find that while some of them enjoy too much independence to be brought back under the wings of the corporate parent, other subsidiaries must be deemed to have their COMI located at the group' headquarters.

Attention should therefore be paid to the nature of the subsidiary. A trading company with operations of its own will certainly deserve closer scrutiny than an empty shell whose sole purpose is to serve as conduit for some of the parent's operations. In the first case, the threshold to find that the subsidiary's COMI coincides with that of the parent company will be much higher than in the second case. When the subsidiary develops activities of its own, one may assume that it is independent if no evidence to the contrary is adduced. ${ }^{75}$ In order to reverse this presumption, one will apply the command and control test and verify that the parent company controls the subsidiary not only through the directors it appoints, but also at all levels of management and in respect of major decisions affecting the subsidiary. ${ }^{76}$

75 Compare with the distinction made by R. Damman, « L'application du Règlement (CE) n 1346/2000 à l'insolvabilité d'un groupe de sociétés après les arrêts Staublitz-Schreiber et Eurofood de la CJCE », at p. 1. According to Damman, «on peut distinguer au moins trois cas de figure. La filiale peut exercer une véritable activité économique dans l'Etat de son siège statutaire et jouir d'une réelle indépendance financière par rapport à sa société mère. Certes, ses organes dirigeants sont nommés par son actionnaire unique. Mais, en pratique, la filiale est gérée d'une manière autonome. Dans une configuration différente, la filiale peut exercer une réelle activité économique dans le pays de son siège statutaire avec de nombreux salariés, y posséder la totalité de ses actifs. Toutefois sa gestion peut être étroitemet contrôlée par la société mère qui détermine sa politique commerciale et gère les relations avec les fournisseurs, clients et banquiers. Dans ce cas, la filiale est dépourvue d'une véritable autonomie financière. L'insolvabilité de la société mère entraîne inexorablement celle de la filiale. Enfin, la filiale peut être une société 'boîte aux lettres' immatriculée dans un Etat sans y exercer la moindre activité économique ou y posséder des actifs ».

76 One should, however, not require the same evidence as is required to pierce the corporate veil. In order to displace the corporate personality of the debtor, it is generally required to show that the parent company has manifeslty ignored this personality. Under the command and control test, it is 
Some types of subsidiaries raise more difficult questions. This is the case for special purpose vehicles incorporated, for tax reasons, in Ireland or for holding companies incorporated, for the same reasons, in the Netherlands. In the first case, the debtor may have developed activities of its own, mainly participation in financial transactions. In the second case, the debtor will at most be engaged in various operations relating to the capital of the subsidiaries. ${ }^{77}$ In both cases, the company's stated purpose it to serve as a corporate recipient of operations or assets engineered or owned by another corporation. It is submitted that in respect of such entities, objective elements cannot be decisive on their own. They must be supplemented by taking into account the legitimate expectations of third parties. ${ }^{78}$ Coordination centers on the other hand, as they are organized under Belgian tax law, should as a rule not raise difficulties. They may be under direct and strict control of a parent company but the activity they develop in Belgium should be sufficient to justify the jurisdiction of the courts of this country. ${ }^{79}$ Finally, in respect of subsidiaries, one should also take into account the ownership structure. It is obvious that if a company owns $100 \%$ or at least a majority of the shareholders' voting rights in the subsidiary, the court will more easily come to the conclusion that the subsidiary's COMI coincides with that of the parent company than if the subsidiary is in effect a joint venture involving another partner.

\section{Lesson 9 : The importance of creditors and their legitimate expectations}

Both the Regulation and the Virgos-Schmit Report underline the importance of third parties and their expectations. ${ }^{80}$ The $13^{\text {th }}$ Recital of the Regulation's Preamble refers to the fact that the place where the COMI is located must be «ascertainable by third parties ». The Virgos-Schmit Report explains that

«The rationale of this rule is not difficult to explain. Insolvency is a foreseeable risk. It is therefore important that international jurisdiction . . . be based on a place known to the debtor's potential creditors. This enables the legal risks which would have to be assumed in the case of insolvency to be calculated $\gg .{ }^{81}$

Courts have followed this injunction and often relied on the third parties' perception In Geveran Trading Company Ltd. v. Skjevesland, ${ }^{82}$ the Chancery Division held that:

"It is the need for third parties to ascertain the centre of a debtor's main interests

sufficient to show that the subsidiary does not enjoy the autonomy it could derive fro its legal personality. No showing of abuse is hence required.

77 Some holding companies exercise a thorough control on the activities of their subsidiaries. If this is the case, there is no question that the holding's COMI will not be determine by reference to that of its subsidiaries.

78 As to which, see hereunder 'Lesson 9'.

79 See recently, W. Heyvaert, « ECJ Rulings Extends Belgian Coordination Center Regime », Tax Notes Intl, July 2006 at p. $105 \mathrm{ff}$.

80 In fact other provisions of the Regulation represent an attempt to preserve in so far as possible the legitimate expectations of third parties. This is in particular true for the various exceptions to the application of the lex fori concursus to be found in Article $5 \mathrm{ff}$ of the Regulation.

81 Report Virgos-Schmit, § 75.

82 [2003] BCC 209; [2002] E.W.H.C. 2898 (Ch.). On Appeal, see [2003] BCC 391. 
that is important, because if there are to be insolvency proceedings, the creditors need to know where to go to contact the debtor".

The test based on the creditors' expectations was instrumental in the Eurofood case. The Irish High Court clearly relied on the creditors' expectations to find that the company's COMI was located in Ireland. According to the Court, " the evidence from [the Eurofood creditors] as to their understanding and perception sworn by Ms Jenkins is very strong. Their clear perception was that they were dealing with investments issued by a company that was located in Ireland and was subject to Irish fiscal and regulatory provisions. There is no evidence whatsoever that they considered the company was run out of Italy $\gg$.

In its Eurofood ruling, the ECJ stressed the need to achieve legal certainty and foreseeability. ${ }^{83}$ The Court inferred from this general objective that the criteria used to identify the centre of the main interests must be « ascertainable by third parties $»{ }^{84}$

This is, however, a very timid recognition. The Court indeed did not identify clearly how creditors' expectations are to be measured and how the court should identify the creditors. This could lead to difficulties : one company may have several categories of creditors, whose expectations may not always coincide. To take the example of the two German trading subsidiaries in the Daisytek case : as the High Court in Leeds pointed out, the most important creditors of these companies were their financiers and trade suppliers. It happened that in that case, the business was financed by a factoring agreement organized by the management company in England. The same company supplied $70 \%$ of the goods bought by the French trading company. The court concluded that « a large majority of potential creditors by value (which I regard as the relevant criterion) $\gg$ knew that England was the center of gravity of the group.

Even though the court did not comment further on this issue, one could imagine that the German companies had other creditors, such as their employees and possibly also the local tax and social security authorities. It may be that in terms of money value, these local creditors were not as important as the creditors who had financed the whole activity from England. Nevertheless, using the creditors' expectations as a yardstick to identify the COMI may not be used as an excuse to discriminate between different categories of creditors. It could indeed be very tempting for a court in the Member State where the headquarter of a group is located, to discount the expectations of foreign creditors who have primarily dealt with a local subsidiary.

The Eurofood case also shows that account need to be taken of the nature and qualifications of the creditors. As the Court of Parma rightly pointed out, most third parties in this case who had dealt with Eurofood were professionals such as institutional investors who had specific expertise on the goings and particulars of special purpose vehicles. The Court held that "the third parties who contracted with Eurofood could not fail to recognise, behind its fragile company veil, the real legal and economic entity with whom they were negotiating and on whom they were placing reliance". It is plain that employees of a local subsidiary will not have the same knowledge of that subsidiary's inner machinery and of its dealings with the foreign parent company as the group's bank.

\footnotetext{
83 ECJ, 2 May 2006, case C-341/04, at $\$ 33$.
}

84 ECJ, 2 May 2006, case C-341/04, at $\S 33$. 
As van Gallen has noted, with respect to companies forming a group, some creditors could treat all the debtors as one economic unit while other creditors do not. ${ }^{85}$ The Rover case illustrates this point. While the English court concluded that the creditors of the 8 national distributors "looked to Longbridge" to secure payment of their debts, it can be questioned whether this holds true for all creditors concerned. Certainly, other companies of the MG Rover Group which may have had claims on the local subsidiaries did not expect much help from these subsidiaries.

Can the same, however, be said of the 42 employees of the French subsidiary and of the 119 sub-distributors operating in France - who apparently were owed large amounts of money by SAS Rover France? It is submitted that on a proper appreciation of the facts, one cannot presume that these creditors considered the French subsidiary as a mere instrument of the Rover group.

These examples show that one should tread carefully when reviewing third parties' expectations, which may be as diverse as the categories of creditors. Caution is also in order since expectations are by essence difficult to measure objectively. The story told by a creditor when supporting or opposing a petition to open insolvency proceedings in a given jurisdiction must be checked against objective facts, which may be found in various documents such as credit documentation. Even when supported by such objective factor, expectations remain by essence fleeting and subjective elements which courts should handle with care.

In sum, the creditors' expectation offer some guidance on how to identify the COMI. This element should, however, be taken with the necessary caution as it opens the door to a subjective appreciation.

\section{By way of conclusion}

It is most difficult to offer a conclusion. Certainly, the last word on the COMI has yet to be written. The recent ruling of the ECJ in the Eurofood case offers some guidance on how to construe the concept. The Court's ruling is a clear reminder that courts should not exclusively rely on the control exercised by a parent company over a subsidiary. However, the Eurofood case concerned a particular type of subsidiary, i.e. a special purpose vehicle. Much more could arguably have been learned from a reference to the ECJ in the Dasiytek or the Rover case.

At this stage, one may safely suggest the following approach : first, there is no 'magic' formula to solve the cases where difficulties arise. Cases may differ too much (e.g. a highly centralized group of companies vs. a loose association of corporate bodies only linked by the same corporate identity) to justify such a 'one stop' approach. Second, the best approach seems to be to look at each debtor on its own, even if it is part of a corporate group. Starting point of the inquiry is the factual reality and not the formal one evidenced by by-laws. When faced with a subsidiary or a company otherwise part of a group, the court should consider all existing elements which point to a decisive control exercised by one company over the corporate debtor. To be relevant and justify taking

$85 \quad$ R. van GALlEN (above, note 55 ) at p. 15. 
into consideration the group dimension, this control must go beyond the normal exercise by a parent company of its shareholder's rights over the subsidiary.

Key in this respect is the autonomy enjoyed by the subsidiary and the degree of integration in the group's affairs. Finally, this appreciation must be weighed against the creditors' expectations. It is submitted that those expectations are only relevant if it is demonstrated that the vast majority of creditors entertained the same expectations about the subsidiary's fate. If one category of creditors have other expectations than those held by another category, this element should altogether not be taken into account.

Those expectations can either reinforce the conclusion reached based on the analysis of the subsidiary's autonomy. They can also disprove this conclusion, in which case the court should probably refrain from taking into account the group dimension.

This interpretation will arguably make it more difficult to secure a single 'European filing' for the whole group in one jurisdiction. The Regulation, however, was not meant to guarantee the possibility of such 'one stop European filing'. That some creative practitioners could achieve such European filings in a couple of high profile cases such as MG Rover, Collins \& Aikmans or Emtec, can probably be explained by the fact that the Regulation was pretty much untested or at least by the specific features of the groups of companies concerned.

How imperfect it may be, the interpretation offered above seems a better solution than attempting to phrase in the Regulation a new provision to the effect tat the COMI of the 'ultimate parent company is deemed to be the COMI" of each of the subsidiaries. 